\title{
Actinomycosis with Tonsillar Diseases and its Clinical Significance
}

\author{
Sushna Maharjan ${ }^{1 *}$, Puja Neopane ${ }^{2}$ and Ramesh Parajuli ${ }^{3}$ \\ ${ }^{1}$ Department of Pathology, Chitwan Medical College Teaching Hospital, Nepal \\ ${ }^{2}$ Department of Oral Medicine and Pathology, Health Sciences University of Hokkaido, Japan \\ ${ }^{3}$ Department of Department of Otorhinolaryngology, Chitwan Medical College Teaching Hospital, Nepal
}

Submission: April 26, 2017; Published: May 05, 2017

*Corresponding author: Sushna Maharjan, Department of Pathology, Chitwan Medical College Teaching Hospital (CMC-TH), P.O. Box 42, Bharatpur, Chitwan, Nepal, Email: sushnamaharjan74@gmail.com

\begin{abstract}
Actinomycosis of the tonsils has been reported in a variable percentage of tonsil specimens by several studies. Their relationship with tonsillar diseases has been evaluated in some studies but the results were not consistent. Hence, the role of actinomyces in diseases of the tonsils is not clearly understood and it is still a subject to debate. A wide range of further studies have to be conducted to understand its role in tonsillar diseases.
\end{abstract}

Keywords: Actinomycosis; Debate; Tonsillar diseases

\section{Introduction}

Bacterial colonies, foreign bodies or other artifacts in tonsil specimens are identified as incidental findings. Actinomyces are relatively often encountered on histological examination of tonsils. Actinomyces israeli and Actinomyces naeslundi are the most frequently isolated pathogenic Actinomycetes. They are Gram positive, anaerobic, non acid fast, branching, filamentous and slow growing bacteria; and are commensal bacteria within human oral cavity [1], colon and vagina. Actinomycosis infection is reported in many other anatomic locations of body, such as pharynx, maxilla, mandible, temporal mandibular joint, neck, mediastinum, thyroid gland, salivary gland, middle ear and central nervous system $[2,3]$.

Tonsillectomy is the most common surgical procedure in Otorhinolaryngology department. The surgical excision of palatine tonsils is known as tonsillectomy. Recurrent tonsillitis or tonsillar hypertrophy causing obstructive symptoms such as snoring and sleep apnea are the most common indications for tonsillectomy. Regardless of the indications performing tonsillectomy, in some centers, tonsil specimens are sent routinely to the pathology laboratory for histopathological examination because of the concern that the tonsil might harbor malignancy. However, studies have demonstrated that sending routine tonsil specimens following tonsillectomy operation for histopathological examination are not cost-effective. Actinomycosis and their relationship with tonsillar disease have been evaluated in some studies but the results were not consistent in these studies because of different methodology implied [4-9].

\section{Discussion}

The histological identification of Actinomycosis is straightforward and has a higher yield than culture. It has been believed that culture is classically the most definitive means of identification but there are a high number of false negative results reported. The reason behind this may be due to culture overgrowth by other organisms, failure of growth following antibiotic therapy and failure of growth due to inadequate anaerobic conditions [10]. Hence, the biopsy of infected tissues, including tonsils, is the most preferred diagnostic tool to search tonsillar Actinomycosis histopathologically instead of culturing.

Actinomycetes release proteolytic enzymes which diminish oxidation-reduction potential and leads to proliferation of the organisms that invades the surrounding tissues [10]. The spread of the organism to contiguous tissue is because of disruption 


\section{Global Journal of Otolaryngology}

of anatomical barriers by dental caries or trauma, surgery or another infection. It forms a chronic suppurative inflammation of the involving organs. Hematoxylin and eosin (H\&E) staining can easily detect the Actinomyces colonies which are recognized as aggregates of filamentous basophilic microorganisms arranged in a radial spoke-like fashion called "ray-fungus" appearance $[9,10]$.

The incidence of tonsillar Actinomycosis was reported to be as high as $56 \%$ in the literature [8]. The reason behind the great differences in frequency among different studies may be due to staining technique, indications for surgery and regional differences and variations in the groups of patients studied $[8,9]$. It is also noted, not all specimens of the right and left tonsil from each patient were reported exclusively. Some of them summarized the findings of both sides of tonsils together, as they share almost the same pathology. The colonies identified were not specifically mentioned either present in both specimens or only on one side [5].

Some found women are infected much less frequently than are men [2] but the other study had no gender preponderance [9]. While one study observed the female preponderance [4]. This difference may be explained by methodology of the study, regional differences, environmental, cultural factors and/or women may be more susceptible to infection [11].

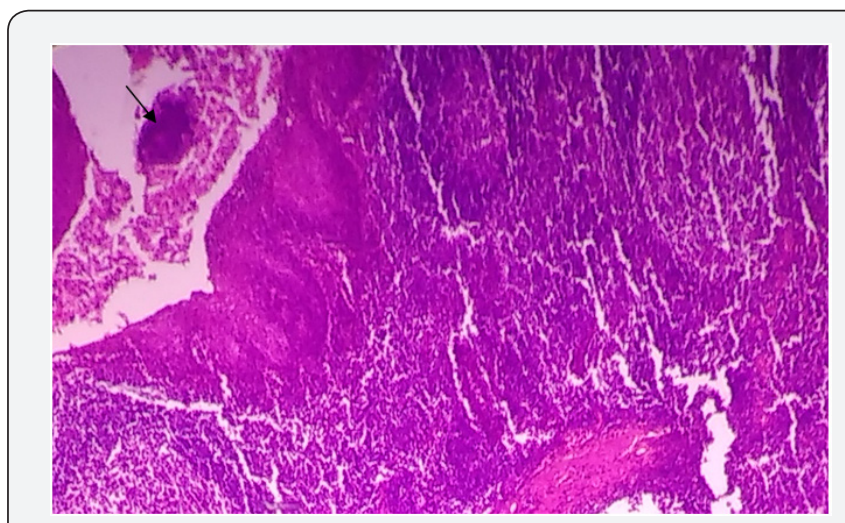

Figure 1: Histopathologic section of tonsil demonstrating a tonsillar Actinomycosis (arrow) (H\&E, original magnification 100 $\mathrm{X})$.

Some authors indicated the possible role of Actinomyces for tonsillar hypertrophy suggesting that Actinomycosis infection of the tonsils may indicate an etiological factor for tonsillar hypertrophy [7-12], while others have not shown correlation between Actinomycosis and recurrent tonsillitis/tonsillar hypertrophy/ tonsillar disease suggesting that the organism as a saprophyte of the normal tonsil [4-6,9,13-15] (Figure 1). The studies have described a wider range of Actinomyces colonizing in tonsillar crypts $[5,8,9]$. Thus, its role in disease of the tonsils is not clearly understood. Though many studies have been conducted to this date, a wide range of further studies have to be performed to understand its role in chronic tonsillitis and tonsillar hypertrophy.

\section{Conclusion}

The role of Actinomyces in diseases of the tonsils is not clearly understood and it is still a subject to debate. A wide range of further studies have to be conducted to understand its role in tonsillar diseases.

\section{References}

1. Schwartz HC, Wilson MC (2001) Cervicofacial actinomycosis following orthognathic surgery: report of 2 cases. J Oral Maxillofac Surg 59(4): 447-449.

2. Richtsmeier WJ, Johns ME (1979) Actinomycosis of the head and neck. CRC Crit Rev Clin Lab Sc 11(2): 175-202.

3. Olson TS, Seid AB, Pransky SM (1989) Actinomycosis of the middle ear. Int J Pediatr Otorhinolaryngol 17(1): 51-55.

4. Yasan H, Ciris M, Ozel BF, Dogru H, Candir O, et al. (2006) The significance of histopathologic tonsillar actinomycosis in pediatric patients with recurrent acute tonsillitis. KBB-Forum 5(1): 1-4.

5. Mohamad I (2009) Actinomyces in the tonsils: Hospital Universiti Sains Malaysia Experience. The Internet Journal of Otorhinolaryngology $8(2): 1-4$.

6. Ashraf MJ, Azarpira N, Khademi B, Hashemi B, Shishegar M, et al. (2011) Relation between Actinomycosis and Histopathological and Clinical Features of the Palatine Tonsils: An Iranian Experience. Iran Red Crescent Med J 13(7): 499-502.

7. Sujatha N, Manimaran M, Rajeswara RN, Kafeel HA, Swayam JS, et al. (2015) Histopathological Features of Tonsils \& Significance of Actinomycosis in Chronic Tonsillitis. IOSR-JDMS 14(4): 105-109.

8. Bhargava D, Bhusnurmath B, Sundaram KR, Raman R, Al Okbi HM, et al. (2001) Tonsillar actinomycosis: a clinicopathological study. Acta Trop 80(2): 163-168

9. Gaffney R, Harrison M, Walsh M, Sweeney E, Cafferkey M (1993) The incidence and role of actinomyces in recurrent acute tonsillitis. Clin Otolaryngol Allied Sci 18(4): 268-271.

10. Pransky SM, Feldman JI, Kearns DB, Seid AB, Billman GF (1991) Actinomycosis in obstructive tonsillar hypertrophy and recurrent tonsillitis. Arch Oto- laryngol Head Neck Surg 117(8): 883-885.

11. Aydin A, Erkilic S, Bayazit YA, Kocer NE, Ozer E, et al. (2005) Relation between actinomycosis and histopathological and clinical features of the palatine tonsils: a comparative study between adult and pediatric patients. Rev Laryngol Otol Rhinol (Bord) 126(2): 95-98.

12. Ozgursoy OB, Kemal O, Saatci MR, Tulunay O (2008) Actinomycosis in the etiology of recurrent tonsillitis and obstructive tonsillar hypertrophy: answer from a histopathologic point of view. J Otolaryngol Head Neck Surg 37(6): 865-869.

13. Toh ST, Yuen HW, Goh YH (2007) Actinomycetes colonization of tonsils: a comparative study between patients with and without recurrent tonsillitis. J Laryngol Otol 121(8): 775-778.

14. Van Lierop AC, Prescott CA, Sinclair Smith CC (2007) An investigation of the significance of Actinomycosis in tonsil disease. Int J Pediatr Otorhinolaryngol 71(12): 1883-1888.

15. Melgarejo MP, Hellin MD, Marco GA, Galindo OX, Ruiz MJA, et al. (2006) A correlation between age and Actinomyces in the adenotonsillar tissue in children. B-ENT 2(2): 95-97. 

(C) Commons Attribution 4.0 License DOI: 10.19080/GJ0.2017.07.555714

\section{Your next submission with Juniper Publishers} will reach you the below assets

- Quality Editorial service

- Swift Peer Review

- Reprints availability

- E-prints Service

- Manuscript Podcast for convenient understanding

- Global attainment for your research

- Manuscript accessibility in different formats

( Pdf, E-pub, Full Text, Audio)

- Unceasing customer service

Track the below URL for one-step submission https://juniperpublishers.com/online-submission.php 